\title{
City Worms (Onychophora): why do fragile invertebrates from an ancient lineage live in heavily urbanized areas?
}

\author{
Julián Monge-Nájera \\ Laboratorio de Ecología Urbana, Universidad Estatal a Distancia (UNED), 2050 San José, Costa Rica; julianmonge@gmail.com
}

Received 07-XII-2017 • Corrected 14-XII-2017 • Accepted 15-XII-2017

\begin{abstract}
Velvet worms, fragile invertebrates from an ancient lineage, are prone to extinction because of their small populations, low vagility and limited geographic ranges. However, I found that 19 species, nearly all of them Latin American and Caribbean peripatids, have been reported from heavily urbanized areas. Onychophoran worms lack most of the characteristics of successful urban animals, but I hypothesize that they survive in cities because diet and undetectability favor them. Citizen scientists could help with the urgent need of learning more about urban onychophorans.
\end{abstract}

Key words: Urban fauna, effects of urbanization, living fossils, Onychophora.

Despite an exception that confirms the rule (Harris, 1991), velvet worms are rare (Peck, 1975; Monge-Nájera, 1995); and their small populations, low vagility and limited geographic ranges (Monge-Nájera \& Lourenço, 1995; Oliveira, Read \& Mayer, 2012) make them good candidates for extinction (Runge et al., 2015). At least three species, Peripatopsis leonina, Peripatopsis clavigera and Opisthopatus roseus are believed lost to habitat modification, including urbanization (Newlands \& Ruhberg, 1978). The fear of losing a fourth to urban development led to a campaign to save the "Dunedin peripatus" in New Zealand (McNeilly, 2015; Barret et al., 2016).

Recently, some onychophoran species have been reported from heavily urbanized areas, for
Resumen: Gusanos de ciudad (Onychophora): ¿por qué invertebrados frágiles de un linaje antiguo viven en áreas fuertemente urbanizadas? Los gusanos de terciopelo, invertebrados frágiles de un linaje antiguo, son muy susceptibles a la extinción por sus pequeñas poblaciones, escasa movilidad y pequeños ámbitos geográficos. Sin embargo, encontré que 19 especies (la mayoría peripátidos de América Latina y el (Caribe) han aparecido en hábitats fuertemente urbanizados. Los onicóforos tienen pocas características de los animales urbanos exitosos, pero propongo que sobreviven en ciudades gracias a su dieta y a que son poco conspicuos. La "ciencia ciudadana" podría ayudar a conocer más de los onicóforos urbanos.

Palabras clave: Fauna urbana, efectos de la urbanización, fósiles vivientes, Onychophora. example Epiperipatus isthmicola from San José, Costa Rica (Barquero et al., 2016), but to my knowledge the subject has not been reviewed. To help researchers and authorities understand and conserve onychophorans, I summarize here the published information on velvet worms living in -or near- human dwellings.

I extracted all records of onychophorans found in towns and cities from sources listed in Digital Table 1, and discarded records with imprecise or unclear locations (for example, Epiperipatus simoni is traditionally thought to have been collected in the city of Caracas, Venezuela, but careful reading of the original record suggests the collector just used the name of the closest city, see Oliveira et al., 2012). For species with reliable 


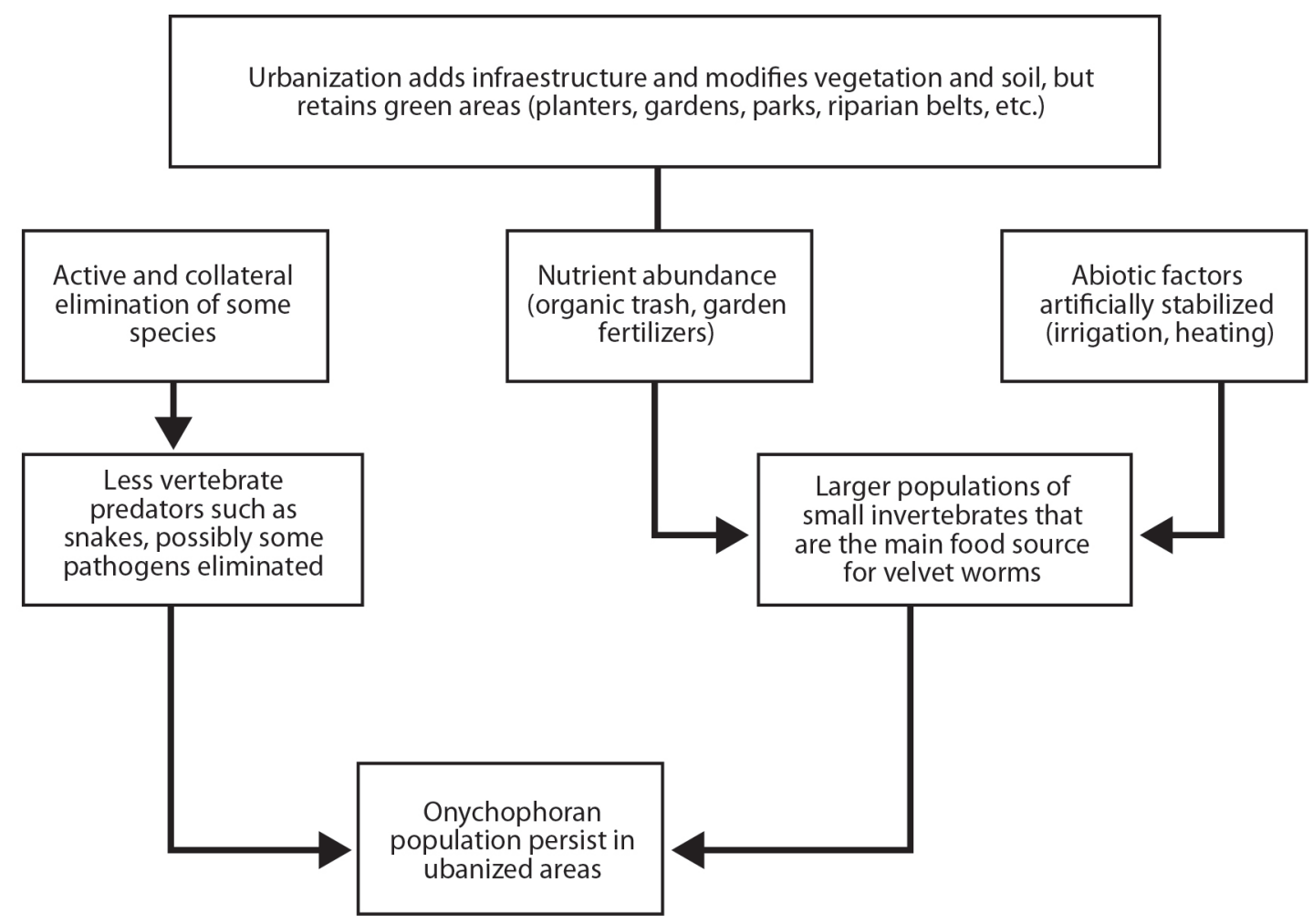

Fig. 1. A simple model to explain the persistence of onychophoran populations in habitats that have been urbanized.

and precise geographic data, I superimposed a grid on satellite photographs of the sites (Digital Appendix 1) to calculate green cover with the formula:

\section{Percent green cover $=100 *$ (points over vegetation area/total points)}

There are reliable records of collection in gardens of cities and suburban houses for 19 species, the majority members of the family Peripatidae in Latin America and smaller Caribbean islands; the only record for the family Peripatopsidae is from the southern island of New Zealand (Digital Figure 1).

The countries with most records (four records each) are Mexico and Brazil (Digital Table 1).

Onychophorans populations are reported from places with up to $92 \%$ of the ground covered by infrastructure (Digital Table 2; Digital Appendix 1).

Traditionally, species have been classified as mostly rural, mostly urban or generalists (McIntyre, 2000), but there are yet no data to justify such labels in onychophorans. Rather, their urban records could represent (1) natural re-colonization of previous habitat; (2) natural or anthropogenic introductions to new habitat; or (3) populations that survived the urbanization of their habitats.

I propose the hypothesis that, in most cases, onychophoran populations in urban and suburban areas belong in the third category: they are survivors of habitat modification. The basis for this hypothesis is that they have been documented to survive fires and volcanic eruptions by moving deeper into the soil (Monge-Nájera, 1995), so they probably survive the comparatively smaller disruption done by human builders. When habitats are "developed", soil burrows are still available in house gardens, sidewalk strips, plant boxes, parks and un-built lots (see Monge-Nájera, Barrientos \& Aguilar, 1993 for details on burrowing behavior).

Onychophorans do not meet most of the characteristics for successful urban animals (Table 1), but their survival in urbanized habitats can be explained by the simple model that I propose in Figure 1. They hide well, hunt only at night, and in urban environments they are protected from climatic extremes and predatory snakes. Furthermore, they can feed on invertebrates attracted by garbage. 
TABLE 1

Characteristics of successful urban animals and comments on how they relate to onychophorans.

Characteristic*

Intelligence to react to complex and changing urban environment

Behavioral plasticity: a rich variety of possible behaviors

Agility to escape the attack of predators and other enemies

Vagility to rapidly move to different parts of the city as needed

Omnivory to take advantage of the many foods types in cities

Undetectability so that humans do not take action to eliminate them

Short reproductive cycle to recover rapidly from population losses

\section{Comment}

Onychophoran brains are small and, like most invertebrates, they are not considered highly intelligent. However, as predators, they can explore relatively large territories and capture prey, so we probably underestimate their intelligence (Monge-Nájera, 1995; Read, 1995).

Onychophorans are slow and lack agility (Monge-Nájera, 1995).

Their vagility is low, onychophorans can only advance a few dozen meters per night (Read, 1985).

They are strictly carnivores (Monge-Nájera, 1995).

Onychophorans are often undetected by humans thanks to their small size, secretive habits, nocturnal activity and underground life (Monge-Nájera, 1995).

Females can reproduce at 15 months and produce a mean 23 young per year (Monge-Nájera, 1994).

* Characteristics of successful urban organisms from Shochat et al. (2006), Møller (2009), and Sol and Lapiedra (2013).

People can be educated not to kill these worms when found in houses and gardens, and to provide additional microhabitats for them and for other invertebrates (Monge-Nájera, 2017). Probably, other species have urban and suburban populations yet to be discovered, and I hope this publication will inspire scientists and "citizen scientists" to increase our knowledge about them, particularly by reporting their occurrence, behavior and ecology.

\section{ACKNOWLEDGMENTS}

I thank Carolina Seas for assistance and two anonymous reviewers for suggestions to improve an earlier draft.

\section{REFERENCES}

Barquero-González, J. P., Cabrera Alvarado, A. A., Valle-Cubero, S., Monge-Nájera, J., \& Morera-Brenes, B. (2016). The geographic distribution of Costa Rican velvet worms (Onychophora: Peripatidae). Revista de Biología Tropical, 64(4), 1401-1414. doi:10.15517/rbt.v64i4.19486

Barrett, D., Recio, M. R., Barratt, B. I., Seddon, P. J., \& van Heezik, Y. (2016). Resource selection by an ancient taxon (Onychophora) in a modern urban landscape:
A multi-scale analysis approach to assist in the conservation of an animal phylum. Landscape and Urban Planning, 148, 27-36.

Cupul-Magaña, F. G., \& Navarrete-Heredia, J. (2008). Rediscovery and new data for Oroperipatus eisenii (Wheeler, 1898) from Mexico (Onychophora: Peripatidae). Entomological News, 119(5), 545-549.

Harris, A. C. (1991). A large aggregation of Peripatoides novaezealandiae (Hutton, 1876)(Onycophora: Peripatopsidae). Journal of the Royal Society of New Zealand, 21(4), 405-406.

McIntyre, N. E. (2000). Ecology of urban arthropods: a review and a call to action. Annals of the Entomological Society of America, 93(4), 825-835.

McNeilly, H. 2015. Killer worm and fault line overcome in $\$ 45 \mathrm{mi}-$ Ilion Dunedin highway project. Stuff (New Zealand), 20 November: http://www.stuff.co.nz/national/74398223/ killer-worm-and-fault-line-overcome-in-45-million-dunedin-highway-project.

Møller, A. P. (2009). Successful city dwellers: a comparative study of the ecological characteristics of urban birds in the Western Palearctic. Oecologia, 159(4), 849-858.

Monge-Nájera, J. \& B. Morera-Brenes (2015). Velvet Worms (Onychophora) in Folklore and Art: Geographic Pattern, Types of Cultural Reference and Public Perception. British Journal of Education, Society \& Behavioural Science 10(3): 1-9, 2015. 
Monge-Nájera, J. (1994). Reproductive trends, habitat type and body characteristics in velvet worms (Onychophora). Revista de Biologia Tropical,42(3), 611-622.

Monge-Nájera, J. (1995). Phylogeny, biogeography and reproductive trends in the Onychophora. Zoological Journal of the Linnean Society, 114, 21-60.

Monge-Nájera, J. (2017). The power of short lectures to improve support for biodiversity conservation of unpopular organisms: an experiment with worms. UNED Research Journal, 9(1), 145-150.

Monge-Nájera, J., \& Lourenço, W. R. (1995). Biogeographic implications of evolutionary trends in onychophorans and scorpions. Biogeographica-Paris,71, 179-186. doi:10.1111/j.1096-3642.1995.tb00111.x

Monge-Nájera, J., \& Morera-Brenes, B. (2016). Velvet worms (Onychophora) in folklore and art: geographic pattern, types of cultural reference and public perception. British Journal of Education, Society \& Behavioural Science, 10(3), 1-9 doi:10.9734/BJESBS/2015/18945

Monge-Nájera, J., Barrientos, Z., \& Aguilar, F. (1993). Behavior of Epiperipatus biolleyi (Onychophora: Peripatidae) under laboratory conditions. Revista de Biología Tropical, 41(3 A), 689-696.

Newlands G., Ruhberg H. (1978) Onychophora. In: Werger M.J.A. (eds) Biogeography and Ecology of Southern Africa. Monographiae Biologicae, vol 31. Springer, Dordrecht

Oliveira, I. de Sena, Read, V. M. S. J., \& Mayer, G. (2012). A world checklist of Onychophora (velvet worms), with notes on nomenclature and status of names. ZooKeys, 211, 1. doi: 10.3897/zookeys.211.3463

Peck, S. B. (1975). A review of the New World Onychophora, with the description of a new cavernicolous genus and species from Jamaica. Psyche, 82(3-4), 341-358. doi:10.1155/1975/98614

Read, V.M.St.J. (1985). The ecology of Macroperipatus torquatus (Kennel) with special reference to feeding and a taxonomic review. Ph.D. Thesis, University College of North Wales, Bangor.

Runge, C. A., Tulloch, A., Hammill, E., Possingham, H. P., \& Fuller, R. A. (2015). Geographic range size and extinction risk assessment in nomadic species. Conservation Biology, 29(3), 865-876.

Sampaio-Costa, C., Chagas-Junior, A., \& Baptista, R. L. (2009). Brazilian species of Onychophora with notes on their taxonomy and distribution. Zoologia (Curitiba), 26(3), 553561. doi:10.1590/S1984-46702009005000004

Shochat, E., Warren, P. S., Faeth, S. H., Mclntyre, N. E., \& Hope, D. (2006). From patterns to emerging processes in mechanistic urban ecology. Trends in ecology \& evolution, 21(4), 186-191.

Sol, D., Lapiedra, O., \& González-Lagos, C. (2013). Behavioural adjustments for a life in the city. Animal Behaviour, 85(5), $1101-1112$.

Xocoyotzin Toledo-Matus, X.; G. Rivera-Velázquez; J. MongeNájera \& B. Morera-Brenes (2018). An undescribed species of velvet worm from Chiapas, Mexico (Onychophora: Peripatidae). UNED Research Journal, 10(1), in press.

\section{EDITED BY CAROLINA SEAS}

See Digital Appendix at: / Ver Apéndice digital en: http://investiga.uned.ac.cr/revistas/index.php/cuadernos 